\title{
Artikel
}

\section{De stand van de stelselherziening: een rijke oogst aan vastgestelde en ontwerpregelgeving}

\author{
Mr. H.W. (Wilco) de Vos*
}

\section{Inleiding}

De afgelopen periode heeft voor de stelselherziening een rijke oogst opgeleverd aan vastgestelde en ontwerpregelgeving. Zo zijn de vier algemene maatregelen van bestuur (AMvB's) op grond van de Omgevingswet ${ }^{1}$ vastgesteld en in het Staatsblad gepubliceerd. ${ }^{2}$ Verder zijn de wetsvoorstellen voor de Invoeringswet Omgevingswet en de Aanvullingswetten natuur en geluid Omgevingswet aan de Tweede Kamer aangeboden. ${ }^{3},{ }^{4}$ Over de ontwerpen van de Aanvullingsbesluiten bodem en 'zwemmen of baden in waterbassins' heeft een openbare internetconsultatie plaatsgevonden. ${ }^{5}$ Tot slot is de 'wet afschaffing actualiseringsplicht bestemmingsplan-

* Mr. H.W. de Vos is werkzaam bij de directie Constitutionele Zaken en Wetgeving van het Ministerie van Binnenlandse Zaken en Koninkrijksrelaties en is als juridisch projectleider betrokken bij de totstandkoming van de nieuwe omgevingswetgeving. Het artikel is op persoonlijke titel geschreven, met dank aan Joris Broers, Jeroen Huijben, Mariska Jacobs, Els Langenbach, Paul Pestman en Masja Stefanski voor hun opmerkingen. De tekst van dit artikel is afgesloten op 17 september 2018.

1. Het Omgevingsbesluit, het Besluit bouwwerken leefomgeving, het Besluit kwaliteit leefomgeving en het Besluit activiteiten leefomgeving.

2. Stb. 2018, 290-293

3. Kamerstukken II 2017/18, 34 986, nrs. 1-2, Kamerstukken II 2017/18, 34 985, nrs. 1-2 en Kamerstukken II 2018/19, 35 054, nrs. 1-2.

4. In het vervolg van deze bijdrage zal kortheidshalve worden gesproken van Invoeringswet en Aanvullingswet natuur, bodem etc. Idem voor wat betreft het Invoeringsbesluit en de Aanvullingsbesluiten.

5. De ontwerpen van het Aanvullingsbesluit bodem Omgevingswet en het Aanvullingsbesluit zwemmen of baden in waterbassins Omgevingswet zijn te raadplegen op www.internetconsultatie.nl. nen en beheersverordeningen' vastgesteld en in werking getreden. ${ }^{6}$

De AMvB's vormen samen met de Omgevingswet de kern van het nieuwe stelsel. Hiermee is het grootste deel van het nieuwe stelsel nu vastgesteld en voor iedereen kenbaar. Ook zijn er geconsolideerde versies beschikbaar van de Omgevingswet met inbegrip van de voorgestelde wijzigingen door de Invoeringswet en de Aanvullingswet natuur. ${ }^{7}$ Daarnaast biedt de publicatie van de ontwerpregelgeving meer duidelijkheid over hoe het nieuwe stelsel eruit komt te zien. Dat is zowel belangrijk voor de verdere uitwerking van het stelsel als belangrijk voor iedereen die zich op de invoering voorbereidt. Met de inwerkingtreding van de Wet afschaffing actualiseringsplicht bestemmingsplannen en beheersverordeningen hebben gemeenten bovendien de zekerheid gekregen dat zij niet, kort voor de inwerkingtreding van de Omgevingswet, de bestaande (digitaal raadpleegbare) plannen en verordeningen hoeven te actualiseren. ${ }^{8} \mathrm{Zij}$ kunnen deze tijd gebruiken voor de voorbereiding op de overgang naar de Omgevingswet.

Tegelijk met de indiening van de wetsvoorstellen zijn de adviezen van de Afdeling advisering van de Raad van State (hierna: de Raad) over de Invoeringswet en de

6. Wet van 18 april 2018 tot wijziging van de Wet ruimtelijke ordening en de Invoeringswet Wet ruimtelijke ordening (afschaffing actualiseringsplicht bestemmingsplannen en beheersverordeningen) (Stb. 2018, 138). Deze wet is met ingang van 1 juli 2018 in werking getreden (Stb. 2018, 203).

7. Zie www.omgevingswetportaal.nl/wet-en-regelgeving/documenten/ publicaties/.

8. Zie voor een korte inhoud van deze wetswijziging de vorige aflevering van deze rubriek: TO 2018, afl. 2, p. 64. 
AMvB's, en de reactie van de regering in het nader rapport, openbaar geworden. ${ }^{9}$ Bijzonder is dat de Raad een integraal advies heeft uitgebracht over de AMvB's en het voorstel voor de Invoeringswet. Dit is gevolgd door een eveneens integraal nader rapport. Over de voorstellen voor de Aanvullingswetten natuur en geluid zijn een afzonderlijk advies en nader rapport uitgebracht. ${ }^{10}$ De adviezen over de AMvB's en de wetsvoorstellen hebben een positief dictum. Een volledige bespreking van deze adviezen en de reactie van de regering voert in het kader van deze rubriek te ver. Wel zullen in de paragrafen 2 en 3 enkele belangrijke punten en wijzigingen worden vermeld die naar aanleiding van het advies in het wetsvoorstel voor de Invoeringswet en de AMvB's zijn angebracht. Paragraaf 4 bevat een korte beschrijving van het advies en het nader rapport over het voorstel voor de Aanvullingswet natuur. Tot slot worden in de paragrafen 5 en 6 enkele andere actuele ontwikkelingen aangestipt.

$\mathrm{Na}$ de indiening van de wetsvoorstellen bij de Tweede Kamer is de behandeling van start gegaan. ${ }^{11}$ Voor het voorstel voor de Aanvullingswet bodem, dat sinds het begin van dit jaar bij de Tweede Kamer aanhangig is, is het verslag al uitgebracht. ${ }^{12}$ De komende periode staat dan ook in het teken van de parlementaire behandeling van deze wetsvoorstellen. Ook daarna blijft het parlement nauw betrokken bij de stelselherziening. De Minister van Binnenlandse Zaken en Koninkrijksrelaties (BZK) heeft in een brief van 26 juni 2018 een overzicht opgenomen van de momenten waarop de nog volgende ontwerpregelgeving aan het parlement zal worden aangeboden. ${ }^{13}$

\section{Eén advies over AMvB's en Invoeringswet}

Ter uitvoering van eerdere toezeggingen ${ }^{14}$ zijn de ontwerp-AMvB's en het voorstel voor de Invoeringswet tegelijk voor advies voorgelegd aan de Afdeling advisering van de Raad van State, zodat de Raad deze in samenhang kan beoordelen. De Raad constateert dat met dit pakket regelgeving de hoofdlijnen van het stelsel zodanig nader worden ingevuld dat (na de totstandkoming van de Omgevingswet) sprake is van een tweede

9. Kamerstukken II 2017/18, 34 986, nr. 4. De adviezen en nader rapporten van de ontwerp-AMvB's zijn gelijkluidend aan die van het voorstel voor de Invoeringswet Omgevingswet en zullen in de Staatscourant worden gepubliceerd.

10. Kamerstukken II 2017/18, 34 985, nr. 4 en Kamerstukken II 2018/19, 35 054, nr. 4

11. De behandeling van het voorstel voor de Invoeringswet wordt voorbereid door de Vaste Commissie voor Binnenlandse Zaken. De behandeling van het voorstel voor de Aanvullingswet natuur Omgevingswet wordt voorbereid door de Vaste Commissie voor Landbouw, Natuur en Voedselkwaliteit.

12. Kamerstukken II 2017/18, 34864 , nr. 5.

13. Kamerstukken II 2017/18, 33 118, nr. 108, p. 2

14. Onder meer naar aanleiding van het advies over het ontwerp van de Omgevingswet. Kamerstukken II 2013/14, 33 962, nr. 4, p. 37. essentiële stap in de stelselherziening. De Raad ziet hierin en in de onderlinge samenhang aanleiding om één integraal advies uit te brengen. ${ }^{15}$ Het betreft een advies op hoofdlijnen, met een positief dictum (dictum 3). Dat geldt dus zowel voor de ontwerp-AMvB's als voor het voorstel voor de Invoeringswet.

Zoals in een vorig nummer van dit tijdschrift ${ }^{16}$ an de orde kwam, heeft de Afdeling advisering van de Raad van State in het advies over het voorstel voor de Aanvullingswet bodem een algemene lijn geformuleerd aan de hand waarvan de Raad zal adviseren over ontwerpregelgeving ter uitvoering van de stelselherziening van het omgevingsrecht. ${ }^{17}$ Volgens die lijn zal de Raad toetsen aan de verbeterdoelen en uitgangspunten van de stelselherziening (zoals een gelijkwaardig beschermingsniveau), de maatschappelijke doelen van de Omgevingswet en de belangrijkste systeemkeuzes. Ook geeft de Raad an dat de nieuwe regelgeving zal worden onderzocht op consistentie met de kerninstrumenten. Verder heeft de Raad aangegeven dat hij de door de wetgever bij de Omgevingswet gemaakte keuzes voor het nieuwe stelsel, waaronder de keuze van de $\mathrm{AMvB}$ als basisniveau voor inhoudelijke normstelling, als uitgangspunt neemt voor de verdere advisering. Deze algemene lijn is ook gehanteerd bij de advisering over het voorstel voor de Invoeringswet en de ontwerp-AMvB's.

De hoofdlijn van het advies is in de onderdelen A en B opgenomen. In het algemeen oordeel spreekt de Raad waardering uit voor de wijze waarop het stelsel in de ontwerpregelgeving is uitgewerkt, ${ }^{18}$ maar wijst er tegelijk op dat voor het halen van de doelen van de stelselherziening de uitvoering in de praktijk cruciaal is. De Raad stelt:

'Uitgaande van de gemaakte keuzes is de Afdeling van oordeel dat het nu voorliggende pakket een consistente en helder gestructureerde invulling aan het stelsel geeft. De praktijk zal echter moeten uitwijzen of de doelstellingen van de stelselherziening uiteindelijk zullen worden gehaald. ${ }^{19}$

De Raad wijst op risico's met het oog op het feitelijk halen van de doelen van de stelselherziening en vraagt nadrukkelijk aandacht voor onderwerpen als flexibiliteit en gelijkwaardige bescherming. Dit leidt, naast concrete aanbevelingen, tot het algemene advies om aan deze onderwerpen specifiek aandacht te besteden bij de geplande evaluatie van de Omgevingswet. De regering heeft in het nader rapport toegezegd daaraan gevolg te geven en dit ook tot uitdrukking gebracht in de memorie van toelichting van het voorstel voor de Invoeringswet. De Raad wijst verder op het belang van ICT en de

15. Kamerstukken II $2017 / 18,34864$, nr. 4, p. 4 en 5. Hieraan is zo uitvoering gegeven dat er vijf gelijkluidende adviezen en nader rapporten zijn vastgesteld.

16. TO 2018, afl. 2, p. 62

17. Kamerstukken II 2018/19, 34 864, nr. 4.

18. Kamerstukken II 2017/18, 34 864, nr. 4, p. 8

19. Kamerstukken II 2017/18, 34 864, nr. 4, p. 8. 
noodzaak van voldoende bestuurskracht. In verband met invoeringsrisico's benadrukt de Raad het belang van begeleiding en monitoring bij de invoering. Dit belang wordt door de regering onderkend. Zowel in het nader rapport als in de memorie van toelichting wordt uitgebreid ingegaan op de invoeringsondersteuning. Daarbij zullen de samenwerking met gemeenten, provincies en waterschappen en de uitvoering van het Bestuursakkoord implementatie Omgevingswet worden voortgezet. Daarnaast zijn maatregelen getroffen om de implementatieopgave te beperken, onder meer door overgangsrechtelijke voorzieningen (bruidsschat) en aanpassingen in de regeling van het Digitaal Stelsel Omgevingswet (zie hierna in par. 3). De voorbereiding op de invoering van de Omgevingswet zal de komende jaren worden gemonitord via de Monitor Omgevingswet. Die zal ook worden gebruikt om de Eerste en Tweede Kamer te informeren over de voortgang van de implementatie. Op die manier zal de ontwikkeling nauwlettend worden gevolgd en kan zo nodig tijdig worden bijgestuurd.

\section{Enkele belangrijke onderwerpen en wijzigingen}

In de onderdelen $\mathrm{C}$ tot en met $\mathrm{G}$ van het advies en het nader rapport worden diverse onderwerpen specifieker behandeld. Hieronder wordt ingegaan op enkele belangrijke punten uit het advies en wordt beschreven tot welke wijzigingen die hebben geleid. Dit betreft slechts een selectie. Het advies en het nader rapport bevatten tezamen een aanzienlijke hoeveelheid informatie over de werking van het stelsel. Daarnaast zijn naar aanleiding van het advies de nota's van toelichting van de AMvB's en de memorie van toelichting bij het voorstel voor de Invoeringswet op diverse punten aangevuld. De wijzigingen in de regelgeving betreffen met name het voorstel voor de Invoeringswet en enkele aanscherpingen van de implementatie van Europeesrechtelijke en internationale verplichtingen in het Besluit kwaliteit leefomgeving. Tot slot is een aantal andere wijzigingen ambtshalve aangebracht. Hierop wordt aan het slot van deze paragraaf ingegaan.

\section{Beschouwing over flexibiliteit in het stelsel}

Een belangrijk thema, dat ook bij de totstandkoming van de Omgevingswet veel aandacht heeft gekregen, is flexibiliteit. De Raad wijst op de ruime mate aan flexibiliteit die het nieuwe stelsel biedt. Daarbij heeft de Raad zorg of de gebruikers van het stelsel voldoende houvast hebben en of de balans tussen beschermen en benutten van de fysieke leefomgeving niet doorslaat naar benutten. In het nader rapport onderbouwt de regering dat er bij de stelselherziening bewust voor gekozen is om de bestuurlijke afwegingsruimte te vergroten, zodat op decentraal niveau beter afgewogen (locatiegerichte) keuzes gemaakt kunnen worden. Daarvoor zijn in het stelsel diverse waarborgen en voorzieningen aangebracht. Zo worden bevoegdheden begrensd door de in de regelgeving vast- gelegde oogmerken waarvoor de bevoegdheden kunnen worden toegepast, bijvoorbeeld het waarborgen van de veiligheid of het beschermen van de gezondheid of het milieu. Verder kan worden gedacht aan standaardregels in het Besluit activiteiten leefomgeving (Bal) en het Besluit bouwwerken leefomgeving (Bbl) en aan standaardwaarden en grenswaarden in het Besluit kwaliteit leefomgeving (Bkl), die een kader vormen voor de bestuurlijke afwegingsruimte. Het nader rapport bevat daarvan een aantal voorbeelden. De regering wijst ook op de regeling van de bruidsschat, een bijzondere vorm van overgangsrecht die bij inwerkingtreding van de Omgevingswet een pakket aan regels van rechtswege aan het omgevingsplan of de waterschapsverordening verbindt. Dat biedt gemeenten en waterschappen bij de invoering houvast en zorgt voor continuiteit. Daarnaast gelden uiteraard de algemeen-bestuursrechtelijke regels en beginselen, zoals het motiveringsvereiste. Als van algemeen verbindende voorschriften wordt afgeweken, zal de beslissing daartoe dan ook goed moeten worden onderbouwd. De regering wijst er voorts op dat ook de huidige regelgeving, zij het versnipperd, afwegingsruimte biedt. Daarmee is in de praktijk reeds ervaring opgedaan, die ook bij de toepassing van het nieuwe stelsel kan worden benut. Het wettelijke stelsel bevat volgens de regering een adequaat pakket aan waarborgen die tezamen voor houvast zorgen.

In de reactie gaat de regering nader in op het uitgangspunt van een gelijkwaardig beschermingsniveau. Dit geldt voor het gehele stelsel en heeft betrekking op zowel rechtsbescherming als de kwaliteit van de fysieke leefomgeving. In de doelen van de wet (art. 1.3 van de Omgevingswet) ligt het streven naar een balans tussen beschermen en benutten besloten. Die werkt door naar de uitoefening van taken en bevoegdheden (art. 2.1, eerste lid, van de Omgevingswet) en komt ook tot uitdrukking in de opdracht om regels te stellen met het oog op een evenwichtige toedeling van functies aan locaties (art. 4.2 van de Omgevingswet). Hoewel er op bepaalde onderwerpen, zoals geluid, trilling en geur, sprake is van decentralisatie, worden die onderwerpen niet volledig overgelaten aan de vrije regelruimte. Hiervoor zullen op rijksniveau instructieregels gelden. Verder maken de bestaande regels voor die onderwerpen deel uit van de bruidsschat, zodat die blijven gelden op het moment van inwerkingtreding van het nieuwe stelsel. Hiermee wordt houvast geboden en voorzien in een voortzetting van het beschermingsniveau. Wat betreft de mogelijkheden tot afwijking van algemene regels in het Bal en Bbl wijst de regering op de bestaande mogelijkheden en ervaringen met maatwerk. De uitkomsten van de evaluatie daarvan geven geen indicatie van een eenzijdige toepassing die tot een slechtere (milieu)kwaliteit zou leiden. De mogelijkheden voor maatwerk kunnen overigens ook worden benut voor locatiespecifieke regels ter bescherming van de fysieke leefomgeving.

Met de Raad acht de regering het van belang om te monitoren of het gewenste evenwicht in de praktijk 
inderdaad gevonden wordt. Dit is onderdeel van de implementatiemonitor. De regering bevestigt verder dat bij de wettelijke evaluatie uitdrukkelijk de vraag zal worden betrokken of de balans tussen beschermen en benutten niet naar een van beide kanten doorslaat.

\section{- Afwijking van algemene regels}

De Raad concludeert dat er binnen het nieuwe stelsel maar beperkt sprake is van materiële voorschriften waarvan geen afwijking mogelijk is en gaat vervolgens in op een aantal mogelijkheden tot afwijking, zoals de ontheffing van instructieregels, via het omgevingsplan, maatwerk en het projectbesluit. De Raad benadrukt daarbij het belang van houvast voor burgers, overheid en rechter. In de reactie beschrijft de regering de beoogde werking van het stelsel alsmede de keuzes en de waarborgen die daarin besloten liggen. Daarbij geeft de regering voorbeelden waarin decentrale regels beter op de lokale situatie zijn toegesneden en uiteindelijk meer houvast bieden. Ook schetst de regering naar aanleiding van het advies enkele categorieën gevallen waarin het werken met een specifieke zorgplicht de voorkeur verdient boven een doel- of middelvoorschrift. Het nader rapport bespreekt elk van de door de Raad geschetste afwijkingsmogelijkheden. Naar aanleiding van het advies zijn in het voorstel voor de Invoeringswet en het Bkl wijzigingen aangebracht met het oog op de doorwerking van internationaalrechtelijke verplichtingen naar rijksprojectbesluiten. Hiervoor zijn direct werkende instructieregels opgenomen, vergelijkbaar met de instructieregels die zich tot het omgevingsplan richten (over werelderfgoederen en het Natuurnetwerk Nederland). Ook is het voorstel voor de Invoeringswet aangevuld om te kunnen voorkomen dat een provincie of het Rijk bij een projectbesluit regelgeving van andere overheden, die dient ter implementatie van Europeesrechtelijke of internationaalrechtelijke regelgeving, buiten toepassing kan laten. ${ }^{20}$ Verder zijn op de genoemde punten de toelichtingen van de betreffende regels aangevuld, waarbij duidelijker is aangegeven op welke wijze de regels houvast bieden.

\section{- $\quad$ Taken en bevoegdheden en bestuurlijke verhoudingen} De Raad stelt in zijn advies ook de verhouding tussen centrale en decentrale overheden aan de orde. De Raad spreekt de zorg uit dat de Omgevingswet onvoldoende houvast biedt voor het bepalen van de rol van de verschillende overheden. De regering geeft aan dat die houvast niet minder is dan onder het huidige wettelijke stelsel en wijst op de diverse waarborgen in de wet en de AMvB's. Tegelijkertijd blijven er, net als nu, onderwerpen die niet eenduidig in de regelgeving aan de verantwoordelijkheid van een van de bestuurslagen toebedeeld kunnen worden. In dit verband gaat de Raad in op de toepassing van het subsidiariteitsbeginsel. De zorg is enerzijds dat een 'hoger' bestuursorgaan zijn verantwoordelijkheid niet neemt waar dat wel geboden is, en anderzijds dat er te snel wordt gecorrigeerd en bijge-

20. Nieuw onderdeel in art. 2.23, eerste lid, onder $a$, onder $5^{\circ}$, en 2.25 , eerste lid, onder $\mathrm{a}$, onder $5^{\circ}$, van de Omgevingswet. stuurd naar aanleiding van incidenten. De regering beklemtoont in haar antwoord dat dit primair bestuurlijke vragen zijn. Met het instrument omgevingsvisie, interbestuurlijke afstemming en bestuurlijke afspraken kan tot een duidelijke rolverdeling tussen overheden worden gekomen.

\section{- Omgevingsplan}

Tot slot maakt de Raad een aantal opmerkingen over de inrichting van het omgevingsplan. De Raad heeft begrip voor het streven naar meer globale en flexibele plannen teneinde beter in te kunnen spelen op actuele ontwikkelingen. Met het oog op de rechtszekerheid van burgers en bedrijven doet de Raad enkele aanbevelingen, die onder meer betrekking hebben op de vergunningverlening voor bouwen.

- Vergunningplicht voor boum-en omgevingsplanactiviteiten

In het voorstel voor de Invoeringswet is een regeling opgenomen waarbij voor de vergunningverlening bij bouwen onderscheid wordt gemaakt tussen de (technische) bouwactiviteit en de vergunning voor de planologische aspecten (omgevingsplanactiviteit). Die laatste vergunningplicht wordt in het omgevingsplan geregeld. De Raad adviseert om deze vergunningplicht op wetsniveau te regelen en gemeenten de mogelijkheid te geven hier in het omgevingsplan van af te wijken. Aan dit advies is tegemoetgekomen door op rijksniveau een overgangsrechtelijke voorziening te bieden (als onderdeel van de bruidsschat). Voor die gemeenten die voor 2021 nog geen eigen omgevingsplan hebben gemaakt, blijft daarmee een uitgangssituatie bestaan waarin al het bouwen vergunningplichtig is. Een uitzondering vormt de landelijke uniforme categorie van vergunningvrije bouwwerken (zoals de dakkapel op het achterdakvlak, de vangrails en de ov-chippaal). De vergunningplicht voor de planologische aspecten van bouwen zal als onderdeel van de bruidsschat rechtstreeks in het omgevingsplan worden opgenomen. De bruidsschat zal worden vormgegeven in het Invoeringsbesluit en geldt vanaf het moment van inwerkingtreding van het nieuwe stelsel. Gemeenten kunnen vervolgens, indien gewenst, in het nieuwe omgevingsplan eigen keuzes over de vergunningplicht maken.

\section{- Conformiteitsverklaring en boumvergunning}

De Raad stelt voor om een aparte conformiteitsverklaring in het leven te roepen, zodat initiatiefnemers kunnen toetsen of een voorgenomen bouwplan waarvoor geen vergunning nodig is, voldoet aan de voor het bouwplan geldende regels van het omgevingsplan. Dit advies is niet overgenomen omdat het volgens de regering tot juridificering en een extra instrument leidt, terwijl met de aanvraag om een omgevingsvergunning hetzelfde resultaat kan worden bereikt. Initiatiefnemers kunnen altijd een vergunning aanvragen voor een oordeel over de conformiteit van een bouwplan. Het besluit dat die vergunning niet nodig is omdat het bouwplan voldoet aan de voor dat bouwplan geldende regels uit het omgevingsplan, geeft ook de gewenste zekerheid. 


\section{Digitaal Stelsel Omgevingswet}

De Raad besteedt uitgebreid aandacht aan het Digitaal Stelsel Omgevingswet (DSO). De Raad constateert, net als het Bureau ICT-toetsing, dat het DSO bestuurlijk complex is en acht het verstandig om het stelsel bij inwerkingtreding van de Omgevingswet te beperken tot het noodzakelijke. De Raad doet aanbevelingen over de betrouwbaarheid, de financiering, het toezicht, de informatiehuizen en -producten, de relatie met basisregistraties, de bescherming van persoonsgegevens en de ontsluiting van aanvragen en meldingen. Om aan deze aanbevelingen tegemoet te komen is interbestuurlijk een basisniveau van serviceverlening vastgesteld. Dit basisniveau zal op het moment van inwerkingtreding van de Omgevingswet zijn gerealiseerd. In het voorstel voor de Invoeringswet zijn wijzigingen aangebracht om het realiseren van dit basisniveau, en het verder uitbouwen van het DSO na de inwerkingtreding van de Omgevingswet, mogelijk te maken. De drie belangrijkste wettelijke wijzigingen zijn:

- het schrappen van een apart register voor omgevingsdocumenten. Er zal gebruik worden gemaakt van de generieke publicatievoorziening op basis van de Bekendmakingswet om besluiten op grond van de Omgevingswet bekend te maken. De Bekendmakingswet zal hiertoe worden aangepast;

- het schrappen van de termen informatiehuizen en informatieproducten. In het voorstel voor de Invoeringswet wordt alleen nog gesproken over het ontsluiten van informatie. In het voorstel is een grondslag opgenomen voor het aanwijzen van organisaties die specifieke informatie leveren (art. 20.26 van de Omgevingswet);

- het inperken en vereenvoudigen van de te ontsluiten informatie bij inwerkingtreding. Via het DSO wordt in eerste instantie met name bestaande informatie ontsloten. Dat zal in het begin vaak een koppeling naar de vindplaats zijn. Voor deze vorm van ontsluiten is geen wettelijke voorziening in de Invoeringswet nodig. Op termijn kan informatie worden bewerkt en gecombineerd. Het voorstel voor de Invoeringswet biedt een grondslag om daarvoor nadere standaardisatieregels te stellen.

Twee typen informatie zijn essentieel voor de werking van het DSO en zullen daarom in elk geval via het Invoeringsbesluit worden geregeld. Het betreft ten eerste de informatie uit besluiten en andere rechtsfiguren op grond van de Omgevingswet die beschikbaar zijn in de generieke digitale voorziening voor officiële overheidspublicaties, zoals de algemene regels in het Bal. Ten tweede de informatie uit de huidige voorziening www.ruimtelijkeplannen.nl.

\section{E. Unierechtelijke aspecten}

\section{- $\quad$ Richtlijn luchtkmaliteit}

De Raad vraagt, naar aanleiding van een inspraakreactie van het IPO, of het nieuwe systeem aanzet tot normopvulling voor luchtkwaliteit buiten de aandachtsgebieden. Dat is volgens de regering niet het geval. In het stelsel van de wet zijn verschillende waarborgen ingebouwd om normopvulling en (dreigende) overschrijdingen te voorkomen. Deze worden in het nader rapport beschreven. Het betreft onder meer de monitoringplicht en programmaplicht bij omgevingswaarden, de regeling op basis van de best beschikbare technieken in het Bal en de mogelijkheid voor gemeenten om lokale omgevingswaarden te stellen. Deze waarborgen leiden tot een rem op normopvulling. Anderzijds bieden die waarborgen mogelijkheden om de kwaliteit in een gebied te verbeteren.

In het kader van de richtlijn luchtkwaliteit adviseert de Raad de gemeentelijke programmaplicht bij een dreigende overschrijding van de omgevingswaarden te verbreden tot een gezamenlijke programmaplicht voor Rijk en gemeenten. Dit voorstel is niet overgenomen. Gemeenten zijn, gegeven de aard en omvang van eventuele (dreigende) overschrijdingen van de omgevingswaarden voor fijnstof en stikstofdioxide, ${ }^{21}$ volgens de regering het best in staat maatregelen te treffen die lokale overschrijdingen wegnemen. Een algemene regeling voor dit soort specifieke situaties is daarom niet realistisch. In de praktijk weten overheden elkaar te vinden, aldus de regering.

\section{- $\quad$ Kaderrichtlijn Water (Krm)}

De Raad adviseert mede in relatie tot jurisprudentie van het Hof van Justitie van de Europese Unie over de Kaderrichtlijn Water ${ }^{22}$ om de beoordelingsregels voor wateractiviteiten in art. 8.85 van het $\mathrm{Bkl}$ aan te passen. De opmerkingen van de Raad zijn voor de regering aanleiding geweest om opnieuw naar de relatie tussen Krwdoelen, waterprogramma's en beoordelingsregels te kijken. Dat heeft ertoe geleid dat het betrokken artikel is aangepast. Door de aanpassing blijft wettelijk geborgd dat een vergunning niet verleend kan worden als er strijd ontstaat met de Krw-verplichtingen. Tevens is art. 4.15 van het $\mathrm{Bkl}$ aangepast om te verduidelijken dat de bepaling in overeenstemming is met de jurisprudentie waarnaar de Raad verwijst.

\section{F. Nadeelcompensatie}

Het wetsvoorstel bevat een regeling voor nadeelcompensatie. Dat is de vergoeding van schade die de overheid veroorzaakt in de uitoefening van haar publiekrechtelijke taak of bevoegdheid die uitstijgt boven het normale maatschappelijke risico en een burger of bedrijf onevenredig zwaar treft in vergelijking tot andere burgers of bedrijven. Nadeelcompensatie is daarmee een overkoepelende term voor schade die door de overheid wordt veroorzaakt. Onder nadeelcompensatie wordt ook begrepen wat in de geldende wetgeving wordt verstaan onder planschade. ${ }^{23}$ De voorgestelde regeling sluit aan bij de

21. Voor enkele andere omgevingswaarden - zwaveldioxide, stikstofoxide, voortschrijdend gemiddelde $\mathrm{PM}_{2,5}$ en ozon - was al voorzien om de programmaplicht bij de provincies respectievelijk het Rijk te leggen. Zie art. $4.1 \mathrm{Bkl}$.

22. HvJ EU 1 juli 2015, C-461/13, ECLI:EU:C:2015:433 (Wezer) en HvJ EU 4 mei 2016, C-346/14, ECLI:EU:C:2016:322 (Schwarze Sulm).

23. Kamerstukken II 2017/18, 34 986, nr. 3, p. 17. 
doelen en uitgangspunten van de Omgevingswet, waaronder het vergroten van de mogelijkheden voor uitnodigingsplanologie. De voorstellen zijn erop gericht duidelijkheid te bieden bij wie, waarvoor en wanneer om welke schadevergoeding kan worden verzocht. ${ }^{24}$ Belangrijke veranderingen zijn het verleggen van het moment dat om schadevergoeding kan worden gevraagd en de instelling van een wettelijk forfait.

\section{- Nadeelcompensatie op moment van} vergunningverlening of uitvoering

In de huidige regelgeving kan om schadevergoeding worden gevraagd op het moment van inwerkingtreding van een plan of regel. Dit leidt tot schadeberekening op basis van de (maximale) mogelijkheden die het plan of de regel biedt. In het voorstel voor de Invoeringswet wordt dit moment verlegd naar het moment dat een omgevingsvergunning wordt verleend of met een activiteit is begonnen. Dan kan beter worden vastgesteld wat de werkelijk geleden schade betreft. De Raad ondersteunt de achterliggende motieven voor de keuze uit het wetsvoorstel om het aangrijpingspunt voor een verzoek om schadevergoeding te verschuiven naar het moment van vergunningverlening of het verrichten van de activiteit. De Raad vindt het op zichzelf positief dat de voorgestelde regeling uitgaat van de concrete schade in plaats van de hypothetische of fictieve schade en deelt de behoefte aan meer voorspelbare uitkomsten van de schadeprocedure. Wel maakt de Raad opmerkingen over de voorgestelde uitwerking en doet een aantal aanbevelingen in verband met de duidelijkheid voor burgers en bedrijven.

Zo vergt de wijze van schadeberekening volgens de Raad aandacht, aangezien bij nieuwe ruimtelijke ontwikkelingen schade in de vorm van waardevermindering niet op één moment optreedt maar geleidelijk ontstaat. In navolging van het advies van de Raad is in het voorstel een wettelijke grondslag opgenomen voor de schadeberekening in geval van vergunningverlening. Verder is in de toelichting bij het wetsvoorstel uitgebreider ingegaan op de waardeberekening.

De Raad wijst erop dat als een vergunning of meldplicht ontbreekt, het moment van feitelijk handelen voor derden soms lastig te bepalen is. Om tegemoet te komen aan het advies van de Raad dat het peilmoment van de schade duidelijk moet zijn, is in het voorstel een wettelijke grondslag opgenomen om bij AMvB een informatieverplichting voor bepaalde activiteiten aan te wijzen. Die informatieverplichting zorgt ervoor dat kenbaar is voor derden wanneer een activiteit start en dat zij schadevergoeding kunnen aanvragen.

Tot slot adviseert de Raad een uitzondering te maken voor het geval dat een onroerende zaak wordt verkocht na vaststelling van het omgevingsplan, maar voordat vergunning wordt verleend dan wel de feitelijke uitvoering ter hand wordt genomen. In dat geval treedt de indirecte (schaduw)schade al op een eerder moment op. Dit advies is niet overgenomen. Hiermee zou volgens de regering het uitgangspunt van vergoeding van daadwerkelijke schade weer worden verlaten. Ook ontstaan hierdoor twee schademomenten, wat een nieuwe belemmering kan opleveren voor globale planvorming en waardoor de uitvoeringslasten kunnen toenemen. Verder licht de regering nader toe waarom in het voorstel geen algemene regeling is opgenomen voor schaduwschade. In lijn met eerdere keuzes is de regering van oordeel dat schaduwschadeproblematiek, als die zich voordoet, in de praktijk adequaat wordt opgelost, onder meer door goed omgevingsmanagement. Een algemene regeling voor schaduwschade is volgens de regering complex, en daardoor lastig uitvoerbaar, en zal naar verwachting tot hoge bestuurslasten leiden.

\section{- $\quad$ Een vast mettelijk forfait}

In de voorgestelde regeling is een forfait opgenomen voor de vergoeding van indirecte schade die bestaat uit waardedaling van een onroerende zaak. Dit houdt een wettelijke aftrek in op de schadevergoeding wegens het normaal maatschappelijk risico. De Raad onderschrijft het vergroten van duidelijkheid en voorspelbaarheid dat is beoogd met de vaststelling van een forfait. De Raad meent echter dat het percentage vastgesteld zou moeten worden zonder een afwijkingsmogelijkheid. Naar aanleiding van het advies is het wetsvoorstel zodanig aangepast dat het forfait voor normaal maatschappelijk risico bij indirecte schade vastgesteld wordt op 5\%, en niet op 'in ieder geval' 5\%. Dat geeft initiatiefnemers en benadeelden meer duidelijkheid over de mogelijke omvang van de schadevergoeding.

Naast de bovenbeschreven wijzigingen is op advies van de Raad de toelichting op diverse punten verduidelijkt. Dit betreft bijvoorbeeld het verloop van de schadeprocedure en het omgaan met verschillende of opeenvolgende schadeoorzaken.

\section{G. Bijzondere onderwerpen}

- Voorbereidingsprocedure omgevingsvergunningen

Uitgangspunt in het nieuwe stelsel is dat de beslissing op een aanvraag om een omgevingsvergunning met de reguliere voorbereidingsprocedure wordt voorbereid. Daarnaast zijn in het Omgevingsbesluit gevallen aangewezen waarin de uniforme openbare voorbereidingsprocedure van afdeling 3.4 van de Algemene wet bestuursrecht (Awb) van toepassing is. Via het voorstel voor de Invoeringswet wordt geregeld dat die procedure ook gevolgd wordt op verzoek of met instemming van de aanvrager van een omgevingsvergunning. ${ }^{25}$ De Raad adviseert die laatste keuze beter te motiveren of het bevoegd gezag de bevoegdheid te geven om afdeling 3.4 van de Awb van toepassing te verklaren. De regering heeft naar aanleiding hiervan het algemeen deel van de memorie van toelichting aangevuld met een nadere onderbouwing. Daarin wordt ingegaan op de verhou- 
ding tussen bevoegd gezag en aanvrager. Verder is een mededelingsplicht opgenomen ${ }^{26}$ voor besluiten die met de reguliere procedure zijn voorbereid, zodat belanghebbenden beter geïnformeerd worden. In de mededeling wordt vermeld door wie, binnen welke termijn en bij welk orgaan bezwaar kan worden gemaakt of beroep kan worden ingesteld. Ook zal met het oog op de mogelijkheid tot het indienen van een voorlopige voorziening worden vermeld wanneer de vergunning in werking treedt. Het advies van de Raad om de beslistermijn uit te breiden als instemming van een ander bestuursorgaan is vereist, is niet overgenomen. De regering is van oordeel dat het andere bestuursorgaan in de voorafgaande adviesfase al voldoende tijd krijgt om tot een oordeel te komen. Instemming behelst in feite een check of het eerder gegeven advies op juiste wijze is verwerkt in het besluit.

\section{- Vangnetbepaling}

Met het voorstel voor de Invoeringswet wordt een algemene, strafrechtelijk handhaafbare vangnetbepaling toegevoegd. Daarbij wordt bepaald dat het verboden is een activiteit te verrichten als daardoor aanzienlijke nadelige gevolgen voor de fysieke leefomgeving (dreigen te) ontstaan. De Raad merkt op dat de vangnetbepaling buitengewoon onbepaald is. De Raad adviseert, in de AMvB waarin de vangnetbepaling zal worden uitgewerkt of begrensd, de onduidelijkheid over inhoud en reikwijdte van de vangnetbepaling zo veel mogelijk weg te nemen. Dit voorstel is overgenomen en zal via het Invoeringsbesluit worden geregeld.

- Overgangsrecht omgevingsplan en vergunningen Naar aanleiding van het advies van de Raad is de werking van het omgevingsplan in de overgangsfase, waarin de gemeente zelf nog geen nieuw omgevingsplan heeft vastgesteld, beter uitgelegd. Zo wordt toegelicht dat het omgevingsplan bij de inwerkingtreding van het stelsel een tijdelijk deel kent, waarin bestaande regels en besluiten, zoals bestemmingsplannen en beheersverordeningen, zijn opgenomen. Ook kan daarin via de zogenoemde bruidsschat de inhoud van rijksregels die worden gedecentraliseerd, bijvoorbeeld over activiteiten of aspecten, zoals geluid, geur of trilling, die nu nog in het Activiteitenbesluit milieubeheer zijn geregeld, worden opgenomen. Dit zal verder worden uitgewerkt via het Invoeringsbesluit. Gedurende de overgangsfase, die tot 2028 loopt, geldt voor de regels in het tijdelijke deel een overgangsrechtelijk regime, dat in afdeling 22.1 van de Omgevingswet wordt geregeld. Gemeenten zullen voor de afloop van de overgangstermijn een beslissing moeten nemen over het opnemen van deze regels in (het nieuwe deel van) het omgevingsplan. De regels zullen dan aan alle eisen van het stelsel moeten voldoen. Daarnaast zijn in de memorie van toelichting voorbeelden opgenomen van de overgang van een vergunning voor een inrichting naar vergunningen en algemene regels

26. In art. 16.64, derde lid, van de Omgevingswet. voor activiteiten. Verder is het overgangsrecht in verband hiermee nog op een enkel onderdeel uitgebreid.

\section{- $\quad$ Overige mijzigingen}

Naast de verwerking van het advies van de Raad van State bevat het nader rapport een overzicht van overige wijzigingen die zijn aangebracht. Dit betreft voornamelijk wetstechnische, redactionele wijzigingen, vernummeringen en de actualisatie in verband met inmiddels aangepaste regelgeving of andere ontwikkelingen. Een voorbeeld van dat laatste vormen de aanpassingen in verband met de gewijzigde takkverdeling en benaming van ministers onder het nieuwe kabinet. De wijzigingen zijn in het nader rapport voor het voorstel van de Invoeringswet en elk van de AMvB's inzichtelijk gemaakt. Hieronder worden enkele wijzigingen weergegeven die van belang zijn voor de toepassing van het nieuwe wettelijke stelsel.

Het wetsvoorstel bevat nieuwe aanduidingen voor (vergunningplichtige) activiteiten in afwijking van het omgevingsplan. De algemene benaming daarvoor betreft omgevingsplanactiviteit. Het voorstel bevat ook een specifieke benaming voor omgevingsplanactiviteiten, waarvoor niet met toepassing van de regels in het omgevingsplan een vergunning kan worden verleend of die anderszins in strijd zijn met het omgevingsplan. Deze worden 'buitenplanse omgevingsplanactiviteiten' genoemd. In de bijlage bij de wet zijn hiervoor definities opgenomen. De voorgestelde wijze van regulering is vergelijkbaar met de bestaande regeling van binnenplanse en buitenplanse omgevingsvergunningen op grond van de Wet algemene bepalingen omgevingsrecht.

\section{- $\quad$ Evenwichtige toedeling van functies aan locaties} Een andere wijziging betreft art. 4.2 van de Omgevingswet over de evenwichtige toedeling van functies aan locaties. De bestaande formulering bleek in de praktijk enkele vragen op te roepen over de betekenis van functies en andere regels alsmede over de relatie tot de bevoegdheid om regels te stellen op grond van art. 4.1 van de Omgevingswet. Aan de bestaande formulering in art. 4.2 van de Omgevingswet werd ontleend dat het daar ging om een ander type regels waaraan andere eisen behoorden te worden gesteld dan de regels die in art. 4.1 worden genoemd. Om deze relatie te verduidelijken is in art. 4.2 van de Omgevingswet een nieuwe formulering opgenomen. Deze omvat de plicht om, voor het gehele grondgebied van de gemeente, regels te stellen met het oog op een evenwichtige toedeling van functies aan locaties. Art. 4.2, eerste lid, van de Omgevingswet is nu geformuleerd als resultaatsverplichting van de regels die in een omgevingsplan kunnen worden opgenomen. Deze regels zijn te beschouwen als een deelverzameling van de regels die op grond van art. 4.1 van de Omgevingswet worden gesteld met het oog op de doelen van de wet. De nieuwe formulering laat ook ruimte voor een gemeente om niet in alle gevallen expliciet een functie aan een locatie toe te delen, bijvoorbeeld wanneer er generieke regels zijn gesteld die voor de betrokken locatie zorgen voor een evenwichtige toedeling van functies 
aan locaties. Deze regels komen door de verplichting om die aan geo-coördinaten te binden ook tot uitdrukking in de digitale verbeelding van het omgevingsplan. In het verlengde daarvan wordt ook in het voorstel voor de Invoeringswet verduidelijkt dat de mogelijkheid voor de inzet van een reactieve aanwijzing, instructieregels en instructies plaatsvindt met het oog op een evenwichtige toedeling van functies aan locaties.

\section{- Verantwoordelijkheidsverdeling bij meer} vergunninghouders

Via het voorstel voor de Invoeringswet wordt een grondslag opgenomen om de verantwoordelijkheid voor het naleven van de vergunningvoorschriften voor een activiteit tussen meer vergunninghouders te splitsen, zodat iedere vergunninghouder alleen zorg draagt voor de voorschriften voor het deel van de activiteit dat hij verricht. Het artikel vormt de implementatie van art. 4, derde lid, van de richtlijn industriële emissies en beoogt meer flexibiliteit te bieden aan het bedrijfsleven. Deze verdelingsmogelijkheid wordt generiek opengesteld voor alle omgevingsvergunningen. Eventuele uitzonderingen zullen met het Invoeringsbesluit worden aangewezen, bijvoorbeeld het exploiteren van een Seveso-inrichting. Ook is in het wetsvoorstel verduidelijkt wie de vergunninghouder is.

\section{- Bruidsschat materschapsverordening}

De overgangsrechtelijke regeling van de bruidsschat die getroffen is voor het omgevingsplan is ook van toepassing verklaard op de waterschapsverordening. Dit betekent dat bij inwerkingtreding van het nieuwe stelsel gedecentraliseerde activiteiten of aspecten, zoals bepaalde lozingsactiviteiten in regionale wateren, die nu nog bij of krachtens AMvB zijn geregeld, in de waterschapsverordening worden opgenomen. Welke regels dat zijn, zal verder worden uitgewerkt in het Invoeringsbesluit. Gedurende de overgangstermijn geldt daarvoor een overgangsrechtelijk regime. De overgangstermijn zal naar verwachting worden gesteld op twee jaar na de inwerkingtreding van de Omgevingswet, zodat gemeenten bij de vernieuwing van hun omgevingsplan - waar dat nodig is - toepassing kunnen geven aan de nieuwe waterschapsverordening.

\section{Aanvullingswetsvoorstel natuur Omgevingswet}

De Afdeling advisering van de Raad van State heeft over dit wetsvoorstel een positief advies (dictum 3) uitgebracht. Het betreft een relatief kort advies, waarin de Raad vooral ingaat op de verhouding tot de instrumenten van de Omgevingswet, natuurbescherming in het omgevingsplan en de bevoegdheidsstructuur.

\subsection{Verhouding tot instrumenten van de Omgevingswet}

De Raad heeft begrip voor het uitgangspunt dat de bescherming van de natuur, als wezenlijk onderdeel van de fysieke leefomgeving, wordt geregeld in de Omgevingswet. Dat uitgangspunt leidt ertoe dat in het wetsvoorstel de specifieke natuurbeschermingsinstrumenten zo veel mogelijk worden vervangen door de generieke instrumenten van de Omgevingswet. In het wetsvoorstel is een aantal specifieke natuurinstrumenten behouden, zoals de gebiedsaanwijzing en de instandhoudingsdoelstellingen. De Raad ziet de noodzaak in van de keuze voor (het behoud van) deze instrumenten, gelet op de landelijke schaal van de Natura 2000-gebieden en het feit dat hiervoor concrete en gedetailleerde Unierechtelijke regels gelden. De Raad adviseert in de memorie van toelichting nader in te gaan op de verhouding tot en doorwerking naar de instrumenten van de Omgevingswet. Naar aanleiding van de opmerkingen van de Raad is in paragraaf 2.2 van de memorie van toelichting een algemene beschouwing opgenomen over de verhouding tot de instrumenten van de Omgevingswet. Daarbij wordt nader onderbouwd waarom ervoor is gekozen om een aantal specifieke instrumenten van de natuurwetgeving (ministeriële aanwijzingsbesluiten voor Natura 2000-gebieden, de instandhoudingsdoelstellingen, de passende beoordeling van plannen en projecten met mogelijk significante gevolgen voor Natura 2000-gebieden en faunabeheereenheden en -plannen) te continueren in de Omgevingswet en hiervoor geen gebruik te maken van de kerninstrumenten van die wet.

\subsection{Natuurbescherming in het omgevingsplan}

De Raad beveelt aan om in de toelichting nader in te gaan op de verhouding tussen Europeesrechtelijk strikt genormeerde onderwerpen en de integrale afweging in het omgevingsplan. Naar aanleiding van de opmerking van de Raad is in de memorie van toelichting tot uitdrukking gebracht dat, voor zover er sprake is van dwingende Europeesrechtelijke kaders, er geen sprake kan zijn van een integrale afweging in het omgevingsplan. Zo geven de Vogelrichtlijn en de Habitatrichtlijn specifieke kaders die bij de uitoefening van taken en bevoegdheden op grond van de Omgevingswet te allen tijde in acht moeten worden genomen. Dat geldt dus ook bijvoorbeeld bij het toelaten van bepaalde activiteiten in het omgevingsplan. Ook in de toelichting bij de aanwijzingsbesluiten en instandhoudingsdoelstellingen voor Natura 2000-gebieden is nader ingegaan op de doorwerking in andere instrumenten van de Omgevingswet, waaronder het omgevingsplan.

\subsection{Bevoegdheidsstructuur}

De Raad wijst erop dat de bevoegdheidsstructuur in de huidige natuurregelgeving gedetailleerd is geregeld. Met het aanvullingswetsvoorstel wordt aangesloten bij de bevoegdheidsstructuur van de Omgevingswet. De Raad adviseert in de toelichting nader in te gaan op de waarborgen die zijn verbonden aan de gewijzigde bevoegdheidsstructuur, in het bijzonder met betrekking tot een 
gelijkwaardig beschermingsniveau. De regering wijst erop dat de opdracht tot onderlinge afstemming en de mogelijkheid tot samenwerking in art. 2.2 van de Omgevingswet de noodzaak wegnemen om in de wet of uitvoeringsregelingen specifieke overleg- en afstemmingsbepalingen op te nemen. Bestaande afspraken over taakverdeling (onder andere de decentralisatie van natuurtaken naar provincies) en bestuurlijke samenwerking zullen echter door het Rijk worden gecontinueerd. Dit is naar aanleiding van het advies van de Raad in de memorie van toelichting uitdrukkelijk bevestigd. Verder blijft de rijkssturing geborgd door middel van de instrumenten van de Omgevingswet, zoals met behulp van instructie- en beoordelingsregels in het Bkl. Dat verzekert volgens de regering dat het beschermingsniveau van de Wet natuurbescherming in het stelsel van de Omgevingswet wordt gecontinueerd.

Tot slot zijn in het voorstel en de memorie van toelichting de redactionele opmerkingen van de Raad verwerkt en zijn enkele andere wijzigingen aangebracht. Het betreft onder meer de wettelijke verankering van de plicht om een programmatische aanpak stikstof voor Natura 2000-gebieden vast te stellen. Ook worden bestaande ontheffingen en vrijstellingen in verband met het uitzetten van exoten, het bijvoederen van wilde dieren en het gebruik van drijfjacht niet via maatwerk maar via een omgevingsvergunning geregeld. Verder wordt de mogelijkheid om een bestuurlijke boete op te leggen verbreed tot alle overtredingen van de regels over de handel in dieren of planten van bedreigde soorten, of van de regels over beschermd hout of producten daarvan. In paragraaf 5 van het nader rapport is een compleet overzicht opgenomen. Tot slot is vermeldenswaard dat er transponeringstabellen zijn gepubliceerd van de omzetting van de Wet natuurbescherming naar het stelsel van de Omgevingswet alsmede van de omzetting van de relevante internationaalrechtelijke bepalingen (onder andere de Vogel- en Habitatrichtlijn) naar het nieuwe stelsel. ${ }^{27}$

\section{Komende ontwikkelingen}

Ook voor andere onderdelen van de stelselherziening zijn er ontwikkelingen te melden. Hieronder een kort overzicht.

\subsection{Aanvullingswet grondeigendom}

Het wetsvoorstel is in maart 2018 voorgelegd aan de Afdeling advisering van de Raad van State. De Raad heeft op 3 augustus 2018 advies uitgebracht. ${ }^{28}$ Dit advies wordt momenteel verwerkt. De eerstvolgende stap is het uitbrengen van het nader rapport en de indiening van het voorstel bij de Tweede Kamer.

\subsection{Aanvullingswet geluid}

Op 5 oktober 2018 is het voorstel voor de Aanvullingswet geluid ingediend bij de Tweede Kamer. ${ }^{29}$ Dit betekent dat ook voor dit wetsvoorstel de parlementaire behandeling van start gaat. Over het voorstel heeft de Afdeling advisering van de Raad van State een positief advies uitgebracht. ${ }^{30}$ Naar aanleiding van het advies zijn enkele wijzigingen aangebracht. Een belangrijke wijziging is dat geluidproductieplafonds als omgevingswaarde zullen worden vastgesteld. Dit gaat gepaard met enkele wijzigingen van de regels in de Omgevingswet over omgevingswaarden en de programmaplicht bij een (dreigende) overschrijding. In een volgend nummer van TO zal hierop nader worden ingegaan.

\subsection{De Omgevingsregeling, het Invoeringsbesluit en de Aanvullingsbesluiten}

De AMvB's en de voorstellen voor de Invoeringswet en de Aanvullingswetten leggen op hun beurt weer de basis voor de uitwerking via de Omgevingsregeling, het Invoeringsbesluit en de Aanvullingsbesluiten. Over de hoofdlijnen van het Invoeringsbesluit Omgevingswet heeft de Minister van BZK in de zomer een brief aan beide Kamers gezonden. ${ }^{31}$ Die geeft een beschrijving van de uitwerking van de belangrijkste onderwerpen, zoals de regeling van het overgangsrecht, waaronder de bruidsschat, en de uitwerking van de regels over het DSO. Ook zullen via het Invoeringsbesluit de AMvB's op grond van de Omgevingswet worden aangevuld. Zo zal daarin de uitwerking van de nieuwe opzet van de vergunningplicht voor bouwactiviteiten haar beslag krijgen. Tot slot zullen via het Invoeringsbesluit de bestaande AMvB's worden aangepast of ingetrokken in verband met de stelselherziening, en wordt in verband daarmee in overgangsrecht voorzien.

De teksten van de Omgevingsregeling, het Invoeringsbesluit en de overige Aanvullingsbesluiten zijn in ambtelijke voorbereiding. De eerstvolgende stap voor elk van die regelingen is dat het ontwerp voor openbare consultatie op internet zal worden gepubliceerd.

\section{Slot}

Zoals in de inleiding al is gezegd, staat de stelselherziening de komende tijd in het teken van de parlementaire behandeling van de verschillende bij de Tweede Kamer aanhangige wetsvoorstellen. Verder kunnen partijen zich in de praktijk verder op het nieuwe stelsel voorbereiden aan de hand van de regelgeving die in de afgelopen periode tot stand is gekomen. Terecht heeft de Afdeling advisering van de Raad van State gewezen op het belang van een goede uitvoering in de praktijk.
29. Kamerstukken II 2018/19, 35 054, nrs. 1-2.

30. Kamerstukken II 2018/19, 35 054, nr. 4.

31. Kamerstukken II 2017/18, 33 118, nr. 111. 
Over de voortgang van de implementatie van het nieuwe stelsel heeft de Minister van BZK in de zomer een brief aan beide Kamers gezonden. ${ }^{32}$ Daarin wordt onder meer ingegaan op de ontwikkeling van het DSO en de samenwerking met gemeenten, waterschappen en provincies bij de voorbereiding op de invoering van het nieuwe stelsel. Uit de implementatiemonitor blijkt dat steeds meer overheden al aan de slag zijn met de nieuwe wettelijke instrumenten. Zo geeft in december 2017 meer dan de helft van de gemeenten aan bezig te zijn met de omgevingsvisie $(57 \%)$ of deze al te hebben vastgesteld $(10 \%)$. De meeste provincies zijn ermee bezig, een kwart heeft de visie zelfs al vastgesteld en gepubliceerd. Op rijksniveau wordt gewerkt aan de nationale omgevingsvisie (NOVI). Hierover volgt een afzonderlijke voortgangsbrief. Verder wordt er door 39\% van de gemeenten al geëxperimenteerd met het bestemmingsplan met verbrede reikwijdte op grond van de Crisis- en herstelwet (Chw). De mogelijkheden om te experimenteren met de instrumenten uit de Omgevingswet worden verder vergroot met het voorstel tot wijziging van de Chw, dat op 5 september 2018 bij de Tweede Kamer is ingediend. ${ }^{33}$

Deze voortekenen zijn bemoedigend voor een goede invoering van het nieuwe stelsel. De transitie naar het stelsel van de Omgevingswet zal de komende jaren van alle partijen nog flink wat inspanning vergen. Niet voor niets heet het samenwerkingsverband van gemeenten (VNG), provincies (IPO), waterschappen (UvW) en het Rijk: 'Aan de slag met de Omgevingswet'. In dat kader worden volop ervaringen gedeeld. Deze vormen een interessante bron van informatie over de toepassingsmogelijkheden van de nieuwe instrumenten. Ze zijn te vinden op: https://aandeslagmetdeomgevingswet.nl.

32. Kamerstukken II 2017/18, 33 118, nr. 110.

33. Het bij koninklijke boodschap van 5 september 2018 ingediende voorstel van wet, tot wijziging van de Crisis- en herstelwet in verband met het versnellen van woningbouw en het faciliteren van duurzame ontwikkeling, zoals het verduurzamen van het energiegebruik (Kamerstukken II 2017/18, 35 013, nrs. 1-2). 